\title{
Factors Influencing Hematopoietic Stem Cell Donation
}

\author{
Amany Abdrbo ${ }^{1}, \mathrm{PhD}$, Salwa Hassanein ${ }^{2}, \mathrm{PhD}$, Ghufran Albajhan ${ }^{3}$, \\ and Fatimah Alsabi ${ }^{4}$. \\ I'Nursing Administration Department, Faculty of Nursing, Cairo University, Egypt and Nursing Management \\ Department, College of Nursing/ King Saud Bin Abdulaziz University for Health Sciences , KSA) \\ ${ }^{2}$ (Community Health Nursing Department, Faculty of Nursing, Cairo University, Egypt and Community Health \\ Nursing Department, College of Nursing/ King Saud Bin Abdulaziz University for Health Sciences, KSA) \\ ${ }^{3,4}$ (Students, College of Nursing/ King Saud Bin Abdulaziz University for Health Sciences, KSA)
}

\begin{abstract}
The study aimed to assess factors influencing hematopoietic stem cell donation in the population of the eastern region of Saudi Arabia. A descriptive, cross-sectional design with a convenience sample technique was used to collect data from a total of 612 adults from the community. Participants completed a selfadministered survey, which included demographic information, knowledge, attitudes, and experience with the donation process. Participants' average age was 28.92 ( $S D=8.63)$; just over half of them were married ( $n=209,51.4 \%)$; and most were college students ( $n=436,71.5 \%)$; Most of the participants $(n=417,70.9 \%)$ knowledge about hematopoietic stem cell donation was classified as low; $47.2 \%(n=288)$ were willing to donate to family members and unrelated individuals, but only $5.2 \%(n=32)$ were already registered as donors. Factors affecting hematopoietic stem cell donation included marital status (married), occupation (college students) and having greater knowledge about donations. There was a significant relationship between attitude toward donation and whether or not someone has actually registered (behavior). It is vital that healthcare providers establish sustainable awareness programs that target prospective donors at different locations.
\end{abstract}

Keywords: Attitude, Behavior, Hematopoietic Stem Cell Donation, Knowledge, and Survey

\section{Introduction}

Stem cells are accountable for the constant production of billions of blood and immune cells each day [1]. They have the ability of self-renewal, and can differentiate to become any specialized cells [2]. Hematopoietic stem cell transplantation is usually an intravenous infusion to patients used to replace unhealthy cells. This transplantation is needed to correct hematopoietic function in patients with bone marrow damage or compromised immune systems, which are often caused by malignant and nonmalignant blood diseases [3, 4].

Stem cells can potentially treat a wide scope of diseases and conditions, such as severe aplastic anemia, chronic myeloid leukemia, thalassemia, and sickle cell anemia, which all have a high prevalence in the Eastern Mediterranean region [5, 6]. Hematopoietic stem cell donations (HSCD) can be from family members or unrelated individuals if family members don't match [4]. About $30 \%$ of patients cannot find a matched family donor $[3,7]$.

The Saudi Stem Cell Donor Registry, the first such registry in the Arab world, was established in 2011 to recruit non-relative compatible donors [5]. The registry has collected about 11,000 stem cell donors, which is relatively insignificant compared to the number of patients in need [8]. There is a yearly need for about 2000 to 2500 stem cell transplantations in Saudi Arabia [8]. However, only 400 to 500 stem cell transplants actually take place, which means the chances of finding a compatible donor are about $10 \%$, and $40 \%-60 \%$ of patients cannot find compatible donors $[8,9]$.

Since matched donors are limited, investigating factors influencing HSCD and learning about which factors may hinder individuals in the eastern region from donating can help in recruiting more donors overall. The aims of this study are to assess factors influencing HSCD in eastern region of Saudi Arabia (age, gender, marital status, health status, occupation, economic status, educational level, knowledge about stem functions and donation, attitude toward donation and actually deciding to join the donor registry (behavior) to assess factors preventing participants from donating hematopoietic stem cells to their families and unrelated individuals; and to assess the relationship between attitudes toward donation and the act of registering to donate.

\section{Literature Review}

In the literature review, most studies about stem cell have focused on the processes of treatment and donation from a matched family member or non-relative matched donor. Few studies have investigated factors associated with the decision to donate [10-13]. Other studies have investigated barriers that influence people's decision to donate $[14,15]$. 
Laver, Hulsey [14] Studied why African Americans refuse to register to become stem cell donors using a survey. The study indicated that from among the 589 study participants, younger, educated people were more willing to donate and that the main barriers to becoming a donor were cost and lack of opportunity [14]. The other study divided a convenient sample of 20 university students into two groups [15]. One group received information about the risks of stem cell donation. The other group did not receive any information. The study found that people who were exposed to risk information had higher knowledge about but a lower intention to donate. Interestingly, however, females had higher risk perceptions than males, yet males had lower attitudes and intentions toward donation [15].

A study in Switzerland assessed obstacles and motivations that influenced people's enrollment in blood stem cell donation registries or programs [16]. An Internet survey was used to collect data from 3153 participants. The main motives for enrollment were the possibility of saving lives, solidarity with fellow humans, and increasing patients' chances for recovery. On the other hand, lack of general information and information about risks included in hematopoietic stem cell donation were the main obstacles to donation [16].

Few studies investigated how or whether or if factors such as age, ethnicity, gender, knowledge, demographics, cultural influences or attitudes, and fears can affect the decision to donate [7, 17-19].

A cross-sectional study examined the association of ethnicity and race on the decision to donate after finding a match [19]. They interviewed 1158 potential donors who had either agreed or refused to donate after being found to be a potential match between 2007 and 2010. They assessed demographics, culture, psychosocial and donation related characteristics. The results showed a strong association across all ethnicities/races and the decision to donate (white, African American, American Indian, Asian/Pacific Islander and Hispanic). African Americans and Hispanics were significantly encouraged by someone to donate; African Americans had fears of serious complications; Asian/Pacific Islanders had medical concerns; Hispanics and Asians had work and family concerns; and Hispanics had still other concerns that hindered them from donating [19].

Another study in the USA tested the hypothesis that an emotional appeal would lead to higher registration rates than a rational appeal [18]. The participants, 102 medical students, were divided into two groups. One group was exposed to an emotional appeal. The other group was exposed to a rational appeal. They were asked if they would register as donors. Most of the participants who were exposed to an emotional appeal $(85 \%)$ agreed to donate; on the other hand, only $49 \%$ of participants who received a rational appeal agreed to donate [18].

A cross-sectional study in Hong Kong measured the relationship between attitude and variables such as age, gender, education, knowledge, and ethnicity. The study concluded that providing education is crucial in recruiting new donors, and new recruiting strategies are needed because about $51.5 \%$ of the 3535 participants in the study were willing to donate, but still had not registered as potential donors. Most participants who were not willing to donate expressed worries about having pain and other side effects related to donation [17].

A study in Australia surveyed 150 university students about their beliefs, pain and side effects expectations, knowledge, and decision to register for donation [7]. Results indicated that many students thought that a bone marrow transplant was an invasive operation and they were less likely to donate. Students that were willing to donate predicted less pain and fewer side effects, and 1 were less informed than the others about HSCD. Students who knew how to register were also more willing to donate [7].

\subsection{Design and Setting}

\section{Methodology}

A descriptive, cross-sectional survey design was used to collect data from the Eastern region in Kingdom of Saudi Arabia.

\subsection{Sampling}

A total of 612 adults between 18 and 60 years old were recruited using a convenience sample technique from the community.

\subsection{Instruments}

The study's survey gathers demographic information, knowledge, attitudes about, and the individuals' decisions on whether or not to donate. The survey was adapted from a study done in Hong Kong about factors related to stem cell donation [17]. Only the name of the registry in the questions was changed, and other nonapplicable items that were related to how the participants would prefer to receive information about stem cell donation was deleted.

- Demographic information includes: age, gender, marital status, occupation, citizenship, health status, and economic and educational levels.

- The section concerned with assessing participants' level of stem cell knowledge consisted of 12 items which questions about stem cell functions and donation: the responses were Yes $\backslash$ NolNot sure. Respondents' scores ranged from 0 to 12 . If the respondent got 6 or less, they were categorized as having low knowledge. They were considered highly knowledgeable if the respondent scored from 7 to 12 . 
- Attitude towards donation was measured using one question. The response was classified into 3 options: (1) Willing to donate to family members and others, (2) Willing to donate to family members only, and (3) Unwilling to donate.

- Concerns for family members who were unwilling to donate were measured using 8 multiple response items that included health concerns, fear of pain, fear of after-effects, inadequate knowledge, lack of trust in the healthcare system, worries about family, possible issues with religion, and anxiety about death.

- Factors that prevent participants from registering to donate: 9 multiple response items included health concern, fear of pain, fear of after-effects, inadequate knowledge, lack of trust in the healthcare system, worries about family, possible issues with religion, anxiety about death, and not knowing about Saudi Stem Cell Donation Registry (SSCDR).

- Having made a decision about registering to donate (Behavior): participants were asked if they wanted to register for donation to unrelated individuals. Their possible responses were: (1) yes I have already registered, (2) yes, but I have not registered, and (3) I do not want to register.

- Favorable choice of media to receive information about HSCD: 8 multiple response items included YouTube, TV advertisements, radio broadcast, newspaper, outdoor body advertisements, posters, public forum, and social media. Participants were instructed to select their most preferred means of learning about HSCD.

A bilingual professional specialist translated the questions into the Arabic language and a professional panel of researchers also reviewed it to ensure the content was translated appropriately. The survey took 5-10 minutes to complete.

\subsection{Data Collection Procedure}

Participants completed the self-administered paper survey and/or the electronic version of the survey, which was posted by the investigator on social media for people who live in the Eastern region. Data were collected during the Fall and Spring Semesters of the 2015-2016 academic year.

\subsection{Ethical Consideration}

The study was reviewed and approved by the Nursing College Research Committee and the College of Nursing Council. Participants were informed that their participation was voluntary and anonymous and they had the right to withdraw at any time. In addition, returning the survey or completing it online represented the participants' consent to be included in the study.

\subsection{Statistical Analysis}

Descriptive statistics were used to describe the study participants' characteristics. Means and standard deviations were used for continuous variables. Numbers and percentages were used for categorical variables. Chi-square and ANOVA tests were used to assess factors that influence attitude toward donation. A P-value that is less than or equal to .05 was selected as evidence of statistical significance.

\subsection{Participants' Demographics}

\section{Results}

Participants' average age was $28.92(S D=8.63)$; $91.2 \%$ were Saudi $(n=558)$; married $(n=209,51.4 \%)$; had a higher level of education $(\mathrm{n}=436,71.5 \%$; college level); and rated their health to be about $3.94(S D=1.01)$ on a scale from 1-5. About $32.4 \%(n=195)$ were college students, and $37.8 \%(n=227)$ were working in nonteaching occupations, and $47.2 \%(n=288)$ reported their family's income to be less than 6000 SR (Table 1).

Most of the participants $(n=417,70.9 \%)$ were categorized in the low knowledge group (scored) about HSCD (Table 1). The majority of them $(n=430,70.6 \%)$ were aware that stem cell transplantation can save the lives of patients with leukemia, lymphoma, and blood related genetic diseases, e.g., aplastic anemia and thalassemia (Table 2).

Regarding attitudes toward HSCD, 47.2\% ( $\mathrm{n}=288)$ were willing to donate to family members and unrelated individuals, $32.6 \%(n=199)$ were willing to donate to family members only, and $20.21 \%(n=123)$ were unwilling to donate.

Regarding their status as being registered to donate, only $5.2 \%(n=32)$ indicated that they had already registered as a donor in a registry, while $67.7 \%(n=195)$ indicated that they would like to register but have not registered yet (Table 1 ).

\subsection{Chi-Square Tests Results}

Regarding factors influencing the HSCD, chi-square indicated that there was a significant relationship between attitude toward donation and marital status $\left(\chi^{2}=7.005, \mathrm{df}=2, \mathrm{p}=.030\right) ; 61.3 \%(\mathrm{n}=46)$ of the single participants were unwilling to donate while $56.6 \%(\mathrm{n}=112)$ of the married participants were willing to donate for 
family members and unrelated individuals. Chi-square indicated that there was a significant relationship between attitude toward donation and occupation: students at college were willing to donate $\left(\chi^{2}=42.572, \mathrm{df}=\right.$ $8, \mathrm{p}=.000)$, but the low knowledge group was unwilling to donate $\left(\chi^{2}=22.891, \mathrm{df}=2, \mathrm{p}=.000\right)$. Chi-square tests indicated that there were no significant relationships between attitude toward donation and educational level $\left(\chi^{2}=4.128, \mathrm{df}=2, \mathrm{p}=.127\right)$; economic level $\left(\chi^{2}=5.355, \mathrm{df}=6, \mathrm{p}=.499\right)$; gender $\left(\chi^{2}=4.629, \mathrm{df}=2, \mathrm{p}=.099\right)$ and citizenship $\left(\chi^{2}=2.657, \mathrm{df}=2, \mathrm{p}=.265\right)$. Participants' attitude toward donation had a significant relationship with their behavior with respect to registering for the $\operatorname{HSCD}\left(\chi^{2}=286.173, \mathrm{df}=4, \mathrm{p}=.000\right)$ (see Table 3).

\subsection{ANOVA Results}

Participants with a mean age of $27.29(\mathrm{SD}=8.15)$ years were more willing to donate for family members and unrelated individual $(F=14.187, \mathrm{df}=2, \mathrm{p}=.000)$. ANOVA tests also indicated that there was no significance difference among attitude groups and health status self-rating $(F=1.002, \mathrm{df}=2, \mathrm{p}=.609)($ Table 4$)$.

\subsection{Multiple Response Results}

Inadequate knowledge $(\mathrm{n}=292, \% 52.2)$, lack of trust in the health system $(\mathrm{n}=237,42.4 \%)$, and health concerns $(n=230,41.1 \%$ ) were the main factors that held participants back from donating to family. Inadequate knowledge $(\mathrm{n}=262,44.6 \%)$, not knowing about the Saudi Stem Cell Donor Registry $(\mathrm{n}=250,42.5 \%)$, health concerns $(n=210,35.7 \%)$, and lack of trust in the health system $(n=197,33.5 \%)$ were the main factors that held participants back from registering to donate. Participants preferred to receive information about HSCD via social media $(n=454,23.6 \%)$ and YouTube $(n=262,43.2 \%)($ See Table 5$)$.

Table 1: Descriptive Statistics of the Study's Main Variables

\begin{tabular}{|c|c|c|c|}
\hline \multicolumn{2}{|c|}{ Variables } & $N$ & $\%$ \\
\hline \multirow[t]{2}{*}{ Gender } & Female & 457 & 74.7 \\
\hline & Male & 155 & 25.3 \\
\hline \multirow[t]{4}{*}{ Marital status } & Single & 187 & 45.9 \\
\hline & Married & 209 & 51.4 \\
\hline & Divorced & 6 & 1.5 \\
\hline & Widowed & 5 & 1.2 \\
\hline \multirow[t]{2}{*}{ Citizenship } & Saudi & 558 & 91.2 \\
\hline & Non Saudi & 47 & 7.8 \\
\hline \multirow[t]{4}{*}{ Educational level } & Primary School & 11 & 1.8 \\
\hline & Middle School & 37 & 6.1 \\
\hline & High School & 126 & 20.7 \\
\hline & College & 436 & 71.5 \\
\hline \multirow[t]{3}{*}{ Economic Level } & Less Than 6000 & 245 & 40.5 \\
\hline & $6000-10000$ & 217 & 35.9 \\
\hline & More Than 10000 & 142 & 23.5 \\
\hline \multirow[t]{5}{*}{ Occupation } & College Student & 195 & 32.4 \\
\hline & Teaching & 88 & 14.6 \\
\hline & Non-Teaching & 227 & 37.8 \\
\hline & Housewife & 58 & 9.7 \\
\hline & Others & 33 & 5.5 \\
\hline \multirow[t]{3}{*}{ Attitude } & $\begin{array}{l}\text { Willing to donate to family } \\
\text { members and unrelated } \\
\text { individuals }\end{array}$ & 288 & 47.2 \\
\hline & $\begin{array}{l}\text { Willing to donate to family } \\
\text { members only }\end{array}$ & 199 & 32.6 \\
\hline & Unwilling to donate & 123 & 20.2 \\
\hline \multirow{3}{*}{$\begin{array}{l}\text { Behavior: Are you willing to be a } \\
\text { stem cell donor for unrelated } \\
\text { patients }\end{array}$} & $\begin{array}{l}\text { Yes, I have already registered in } \\
\text { the SSDR }\end{array}$ & 32 & 5.2 \\
\hline & $\begin{array}{l}\text { Yes, but I have not yet registered } \\
\text { in the SSDR }\end{array}$ & 228 & 37.4 \\
\hline & No & 350 & 57.4 \\
\hline \multirow[t]{2}{*}{ Knowledge groups } & Low $(=<6)$ & 417 & 70.9 \\
\hline & High (7-12) & 171 & 29.1 \\
\hline Variables & Mean & \multicolumn{2}{|c|}{$S D$} \\
\hline Age & 28.92 & \multicolumn{2}{|c|}{8.63} \\
\hline Health Status (1-5) & 3.94 & \multicolumn{2}{|c|}{1.01} \\
\hline
\end{tabular}


Table 2: Descriptive Statistics for Knowledge about Stem Cell Donation

\begin{tabular}{|c|c|c|c|}
\hline Knowledge & N. & $\%$ & Total N. \\
\hline What is/are the function(s) of stem cells? Produce red blood cells & 294 & 48.0 & 610 \\
\hline What is/are the function(s) of stem cells? Produce white blood cells & 213 & 35.0 & 609 \\
\hline 3. What is/are the function(s) of stem cells? Produce platelets & 307 & 50.7 & 606 \\
\hline Can stem cells regenerate after bone marrow donation? & 413 & 67.9 & 608 \\
\hline Can donors resume normal daily activity within 1-2 days after stem cell donation? & 263 & 43.2 & 609 \\
\hline 6. Will there be any visible scar after stem cell donation? & 100 & 16.4 & 610 \\
\hline 7. Does stem cell donation cause after-effects to the donor? & 147 & 24.1 & 610 \\
\hline 8. Are you aware of a local or international stem cell donor registry? & 109 & 17.9 & 610 \\
\hline $\begin{array}{l}\text { 9. Are you aware that donors of the same ethnic group are better matches for stem cell } \\
\text { transplant? }\end{array}$ & 287 & 47.0 & 610 \\
\hline 10. Can a registered stem cell donor withdraw their registration? & 303 & 49.8 & 609 \\
\hline $\begin{array}{l}\text { 11. Are you aware that stem cell transplantation can save the lives of patients with leukemia, } \\
\text { lymphoma and blood related genetic diseases, e.g., aplastic anemia and thalassemia etc.? }\end{array}$ & 430 & 70.6 & 609 \\
\hline 12. What is the chance of two unrelated people having identical tissue types? & 96 & 15.8 & 609 \\
\hline
\end{tabular}

Table 3: Chi-square Tests and Descriptive Statistics for: Attitude toward Donation by Marital Status ( $\mathrm{N}=407)$

\begin{tabular}{lcc}
\hline Attitude Toward Donation & Single & Marital Status \\
& Married \\
\hline Willing to donate to family members and unrelated individuals & $86(43.4 \%)$ & $112(56.6 \%)$ \\
Willing to donate to family members only & $66(49.3 \%)$ & $68(50.7 \%)$ \\
Unwilling to donate & $46(61.3 \%)$ & $29(38.7 \%)$ \\
\hline
\end{tabular}

Attitude toward Donation by Occupation (N=599)

\begin{tabular}{lccccc}
\hline \multirow{2}{*}{ Attitude Toward Donation } & College Student & Teaching & Non-Teaching & House- wife & Others \\
\hline $\begin{array}{l}\text { Willing to donate to family } \\
\text { members and unrelated }\end{array}$ & $120(42.4 \%)$ & $32(11.3 \%)$ & $100(35.3 \%)$ & $19(6.7 \%)$ & $12(4.2)$ \\
$\begin{array}{l}\text { individuals } \\
\begin{array}{l}\text { Willing to donate to family } \\
\text { members only }\end{array}\end{array}$ & $39(19.8 \%)$ & $45(22.8 \%)$ & $79(40.1 \%)$ & $24(12.2 \%)$ & $10(5.1 \%)$ \\
\begin{tabular}{l} 
Unwilling to donate \\
\hline
\end{tabular} & $36(30.3 \%)$ & $10(8.4 \%)$ & $47(39.5 \%)$ & $15(12.6 \%)$ & $11(9.2 \%)$ \\
\hline
\end{tabular}

Attitude toward Donation by Knowledge $(\mathrm{N}=588)$

\begin{tabular}{lcc}
\hline Attitude Toward Donation & Low $(=<6)$ & Knowledge \\
\hline Willing to donate to family members and unrelated individuals & $181(64.0 \%)$ & $102(36.0 \%)$ \\
Willing to donate to family members only & $138(71.1 \%)$ & $56(28.9 \%)$ \\
Unwilling to donate & $98(88.3 \%)$ & $13(11.7 \%)$ \\
\hline
\end{tabular}

Attitude toward Donation by Educational Level ( $\mathrm{N}=610)$

\begin{tabular}{lcc}
\hline \multirow{2}{*}{ Attitude Toward Donation } & \multicolumn{2}{c}{ Educational Level } \\
& Pre-College & $217(75.3 \%)$ \\
\hline Willing to donate to family members and unrelated individuals & $71(24.7 \%)$ & $134(67.3 \%)$ \\
Willing to donate to family members only & $65(32.7 \%)$ & $85(69.1 \%)$ \\
Unwilling to donate & $38(30.9 \%)$ & \\
\hline
\end{tabular}

Attitude toward Donation by Economic Level $(\mathrm{N}=605)$

\begin{tabular}{lccc}
\hline \multirow{2}{*}{ Attitude Toward Donation } & Economical Level & \\
& Less Than 6000 & $6000-10000$ & More Than 10000 \\
\hline Willing to donate to family members and unrelated individuals & $120(41.8 \%)$ & $103(35.9 \%)$ & $64(22.3 \%)$ \\
Willing to donate to family members only & $73(37.2 \%)$ & $68(34.7 \%)$ & $54(27.6 \%)$ \\
Unwilling to donate & $52(42.6 \%)$ & $46(37.7 \%)$ & $24(19.7 \%)$ \\
\hline
\end{tabular}

\begin{tabular}{lrr}
\multicolumn{2}{c}{ Attitude toward Donation by Gender (N=610) } \\
\hline Attitude Toward Donation & Female & Male \\
\hline Willing to donate to family members and unrelated individuals & $225(78.1 \%)$ & $63(21.9 \%)$ \\
Willing to donate to family members only & $146(73.4 \%)$ & $53(26.6 \%)$ \\
Unwilling to donate & $84(68.3 \%)$ & $39(31.7 \%)$ \\
\hline
\end{tabular}

\begin{tabular}{lcc}
\multicolumn{4}{c}{ Attitude toward Donation by Citizenship (N=605) } \\
\hline Attitude Toward Donation & Saudi & Non-Saudi \\
\hline Willing to donate to family members and unrelated individuals & $259(90.6 \%)$ & $27(9.4 \%)$
\end{tabular}


Willing to donate to family members only

Unwilling to donate

Participant Behavior Regarding HSC Registration for Donation by Attitude $\quad(\mathrm{N}=610)$.

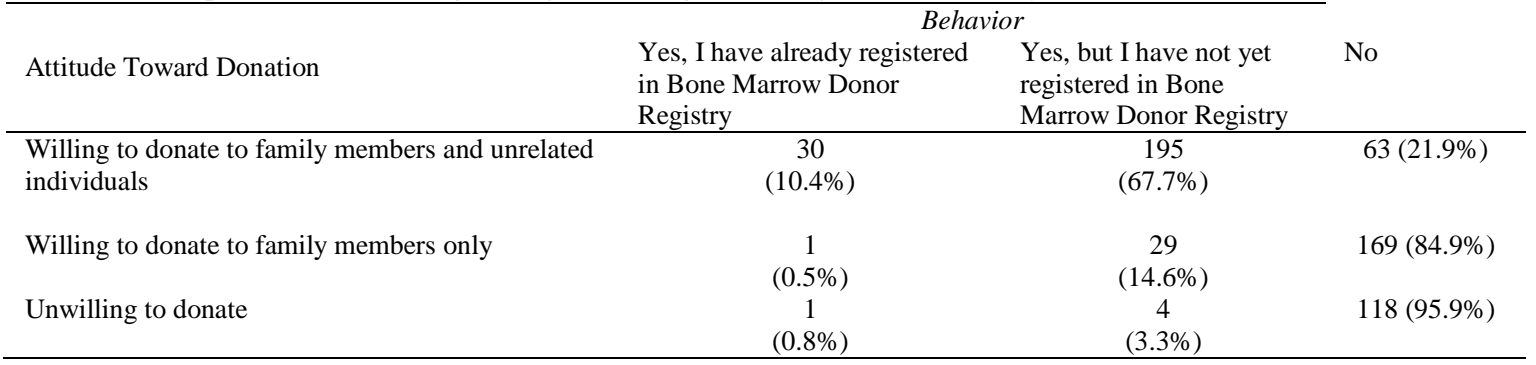

Table 4: ANOVA Test and Descriptive Statistics for: Attitude toward Donation by Age (N=602)

\begin{tabular}{lccc}
\hline Attitude Toward Donation & $N$ & Mean & $S D$ \\
\hline $\begin{array}{l}\text { Willing to donate to family } \\
\text { members and unrelated }\end{array}$ & 285 & 27.29 & 8.15 \\
$\begin{array}{l}\text { individuals } \\
\begin{array}{l}\text { Willing to donate to family } \\
\text { members only }\end{array}\end{array}$ & 195 & 31.47 & 8.98 \\
Unwilling to donate & 122 & 28.70 & 8.32 \\
\hline
\end{tabular}

Attitude toward Donation by Health Status $(\mathrm{N}=610)$

\begin{tabular}{|c|c|c|c|}
\hline Attitude Toward Donation & $N$ & Mean & $S D$ \\
\hline $\begin{array}{l}\text { Willing to donate to family } \\
\text { members and unrelated } \\
\text { individuals }\end{array}$ & 288 & 3.95 & 1.06 \\
\hline $\begin{array}{l}\text { Willing to donate to family } \\
\text { members only }\end{array}$ & 199 & 3.96 & 0.93 \\
\hline Unwilling to donate & 123 & 3.86 & 1.01 \\
\hline
\end{tabular}

Table 5: Descriptive Statistics for Multiple Responses about: Concerns for those Unwilling to Donate (N=559)

\begin{tabular}{lcc}
\hline Concerns for Unwilling to Donate & $N$ & $\%$ of Cases \\
\hline Health Concern & 230 & $41.1 \%$ \\
Afraid of pain & 140 & $25.0 \%$ \\
Afraid of after effect & 184 & $32.9 \%$ \\
Inadequate knowledge & 292 & $52.2 \%$ \\
Lack of trust in the health system & 237 & $42.4 \%$ \\
Family & 64 & $11.4 \%$ \\
Religion & 25 & $4.5 \%$ \\
Death & 56 & $10.0 \%$ \\
Others & 17 & $3.0 \%$ \\
\hline
\end{tabular}

Factors Preventing Participants from Signing up for Donation $(N=588)$

\begin{tabular}{lcc}
\hline Factors Prevent from Signing up for Donate & $N$ & $\%$ of Cases \\
\hline Health Concern & 210 & $35.7 \%$ \\
Afraid of pain & 128 & $21.8 \%$ \\
Afraid of after effect & 172 & $29.3 \%$ \\
Inadequate knowledge & 262 & $44.6 \%$ \\
Lack of trust in the health system & 197 & $33.5 \%$ \\
Family & 65 & $11.1 \%$ \\
Religion & 25 & $4.3 \%$ \\
Death & 48 & $8.2 \%$ \\
I do not know & 250 & $42.5 \%$ \\
Others & 28 & $4.8 \%$ \\
\hline
\end{tabular}

Favorable Media to Receive Information about Donation (N=606)

\begin{tabular}{lcc}
\hline & $N$ & $\%$ of Cases \\
\hline YouTube & 262 & $43.2 \%$ \\
TV Advertisement & 207 & $34.2 \%$ \\
Radio Broadcast & 78 & $12.9 \%$ \\
Newspaper & 113 & $18.6 \%$ \\
Outdoor Body AD & 132 & $21.8 \%$ \\
Posters & 136 & $22.4 \%$ \\
Public Forum & 143 & $23.6 \%$ \\
Social Media & 454 & $74.9 \%$ \\
Others & 28 & $4.6 \%$ \\
\hline
\end{tabular}




\section{Discussion}

One of the factors affecting a person's attitude towards donation was being single. Similarly, a study in America showed that people who live alone are less likely to donate. [14] Occupation had a significant relationship with one's attitude toward HSCD. A high percentage of the college student group in this study was willing to donate for family members and unrelated individuals. In contrast, a study in Hong Kong showed that occupation was not significantly related to willingness to donate [17].

People with high knowledge were willing to donate. However, one study in Australia showed people with less knowledge to be more willing to donate. [7] The current study logically expected to find that with more knowledge about donation, people are more motivated and willing to donate, especially since most of them indicated that they were aware that stem cell transplantation can save the lives of patients with different diseases. Also, a study among African Americans indicated that when they are aware that donation will save lives they are more willing to donate [14]. Another study among Greeks found that knowledge about donation significantly predicted participants' willingness to donate [20].

Participants' attitude toward donation had a significant relationship with their actions with respect to registering for the HSCD (behavior). This seems logical because people's positive attitudes toward donating will guide their decision to register as stem cell donors. The majority of the group that was willing to donate to family and unrelated individuals indicated that they would like to register but had not registered yet, which was in consistent with the study in Hong Kong [17].

Educational level had no significant relationship with attitude to donate in this study. However, it was expected that people with a higher level of education would be motivated to donate. This expectation was aligned with the finding of a study done among African Americans and Caucasians that indicated that with higher levels of education, people were more willing to donate [21]. A study in the USA and another study in Hong Kong both indicated that highly educated people were more willing to donate [14, 17].

Economic level did not have a significant relationship with willingness to donate. On the other hand, a study in the USA found that there was a significant relationship between providing tax breaks and leave provisions and people's willingness to donate [22]. Another study among African Americans indicated that the cost of donation was a factor that hinders them from donating [14].

Even though female participants were the majority of the respondents, gender did not have a significant relationship with willingness to donate in this study. On the other hand, a study in Athens found that among 565 Greek participants, females were significantly more willing to donate [20]. In the current study, participants whose ages were around 27.29 years were willing to donate for family members and unrelated individuals. Likewise, the USA and Hong Kong studies indicated that younger people were more willing to donate $[14,17]$. Meanwhile, a study in Germany found that newly recruited donors were between the ages of 34.0 and 39.7 years old $[21,23]$. This might be because younger people - especially new generations - have access to the internet and social media and can easily obtain information and become enlightened about new treatment strategies such as hematopoietic stem cell transplantation.

Inadequate knowledge was the main reason that prevented participants from donating to family members and/or unrelated individuals. Likewise, a study in Switzerland showed that a lack of general information about HSCD (52.6\%) followed by the lack of risk information (34.6\%) were the main reasons that prevented participants from donating [16]. Lack of trust in the health system was one of the main concerns and factors that hindered participants from donation in the current study. This result was supported by another Greek study that showed that participants' trust in health professionals was an indicator of their willingness to donate [20].

\section{Conclusions And Recommendations}

Factors affecting HSCD included marital status (married), occupation (college students) and high knowledge. There was a significant relationship between attitude toward donation and whether or not someone actually registered to become a donor. In addition, the main factors that prevented participants from donation were inadequate knowledge, a lack of trust in the health system, health concerns, and not knowing about the Saudi Stem Cell Donor Registry. Finally, most participants preferred to receive information about HSCD via social media and YouTube.

The study recommended establishing a community program that includes regular awareness campaigns to target families as well as college students at different locations, such as shopping centers and university campuses. It also recommended using different ways to disseminate information about stem cell donation, such as social media and YouTube, to better educate the public about HSCD and to decrease their concerns. Replication of the study with a larger sample size is needed to be able to generalize the study's findings to larger population. 


\section{Limitations}

Some limitations were present in this study. First, the total number of the study sample varies in each analysis because of missing data, especially data for marital status. However, marital status was significantly related to donation. Consequently, collecting more information about marital status and donation may confirm these results. Second, there might be some bias because of the participants' self-selection and self-reporting to respond to either the paper or electronic survey. That is to say that participants who chose to fill out the survey may be different than non-participants.

\section{References}

[1]. Bethesda. Hematopoietic Stem Cells . In Stem Cell Information. National Institutes of Health, U.S. Department of Health and Human Services. 2011 [cited 2016 January 13]; Available from: http://stemcells.nih.gov/info/scireport/pages/chapter5.aspx.

[2]. Murnaghan, I. Are Stem Cells Important? 201526 Dec , 2015 [cited 2016 January, 14]; Available from: http://www.explorestemcells.co.uk/whyarestemcellsimportant.html.

[3]. Dehn, J., et al., Unrelated donor hematopoietic cell transplantation: factors associated with a better HLA match. Biology of Blood and Marrow Transplantation, 2008. 14(12): p. 1334-1340.

[4]. Perumbeti, A. Hematopoietic Stem Cell Transplantation: Practice Essentials, Overview, Indications for HSCT. 2014 [cited 2016 January, 13]; Available from: http://emedicine.medscape.com/article/208954-overview.

[5]. Abumaree, M.H., et al., Stem Cell Research and Regenerative Medicine at King Abdullah International Medical Research Center. Stem cells and development, 2014. 23(S1): p. 12-16.

[6]. Aljurf, M., et al., Status of hematopoietic stem cell transplantation in the WHO Eastern Mediterranean Region (EMRO). Transfusion and Apheresis Science, 2010. 42(2): p. 169-175.

[7]. Hyde, M.K., P.J. Mclaren, and K.M. White, Identifying belief targets to increase bone marrow registry participation among students who have never donated blood. Psychology, health \& medicine, 2014. 19(1): p. 115-125.

[8]. Haydar, M., "Stem cells » .. treat incurable diseases, however, donors !, in Alriyadh News Paper 2015, Alyamamh Press Saudi Arabia.

[9]. Jawdat, D.M., et al., Chances of finding an HLA-matched sibling: The Saudi experience. Biology of Blood and Marrow Transplantation, 2009. 15(10): p. 1342-1344.

[10]. Kollman, C., et al., Donor characteristics as risk factors in recipients after transplantation of bone marrow from unrelated donors: the effect of donor age. Blood, 2001. 98(7): p. 2043-2051.

[11]. Labott, S. and A. Pfammatter, The influence of the donor-recipient relationship on related donor reactions to stem cell donation. Bone marrow transplantation, 2014. 49(6): p. 831-835.

[12]. Pillay, B., et al., The psychosocial impact of haematopoietic SCT on sibling donors. Bone marrow transplantation, 2012. 47(10): p. 1361-1365.

[13]. Wanner, M., et al., Losing the genetic twin: donor grief after unsuccessful unrelated stem cell transplantation. BMC health services research, 2009. 9(1): p. 2.

[14]. Laver, J.H., et al., Assessment of barriers to bone marrow donation by unrelated African-American potential donors. Biology of Blood and Marrow Transplantation, 2001. 7(1): p. 45-48.

[15]. Mclaren, P.J., M.K. Hyde, and K.M. White, Exploring the role of gender and risk perceptions in people's decisions to register as a bone marrow donor. Health education research, 2012. 27(3): p. 513-522.

[16]. Bart, T., et al., Giving blood and enrolling on the stem cell donor registry: ranking of obstacles and motives in Switzerland. Transfusion Medicine and Hemotherapy, 2014. 41(4): p. 264-272.

[17]. Kwok, J., et al., Factors Influencing Hematopoietic Stem Cell Donation Intention in Hong Kong: A Web-Based Survey. Ann Transplant, 2015. 20: p. 604-13.

[18]. Studts, J., et al., Decisions to register for the National Marrow Donor Program: rational vs emotional appeals. Bone marrow transplantation, 2010. 45(3): p. 422-428.

[19]. Switzer, G.E., et al., Race and ethnicity in decisions about unrelated hematopoietic stem cell donation. Blood, 2013. 121(8): p. 1469-1476.

[20]. Galanis, P., et al. Factors that influence Greeks' decision to register as potential bone marrow donors. in Transplantation proceedings. 10.1016/j.transproceed.2008.03.139. 2008. Elsevier.

[21]. Onitilo, A.A., et al., Race, education, and knowledge of bone marrow registry: indicators of willingness to donate bone marrow among African Americans and Caucasians. Transplant Proc, 2004. 36(10): p. 3212-9.

[22]. Lacetera, N., M. Macis, and S.S. Stith, Removing financial barriers to organ and bone marrow donation: The effect of leave and tax legislation in the US. Journal of health economics, 2014. 33: p. 43-56.

[23]. Schmidt, A., et al., Aging of registered stem cell donors: implications for donor recruitment. Bone marrow transplantation, 2008. 41(7): p. 605-612. 